\title{
Freedom of religion: From the Church Order of Dordt (1619) to South Africa (2018)
}

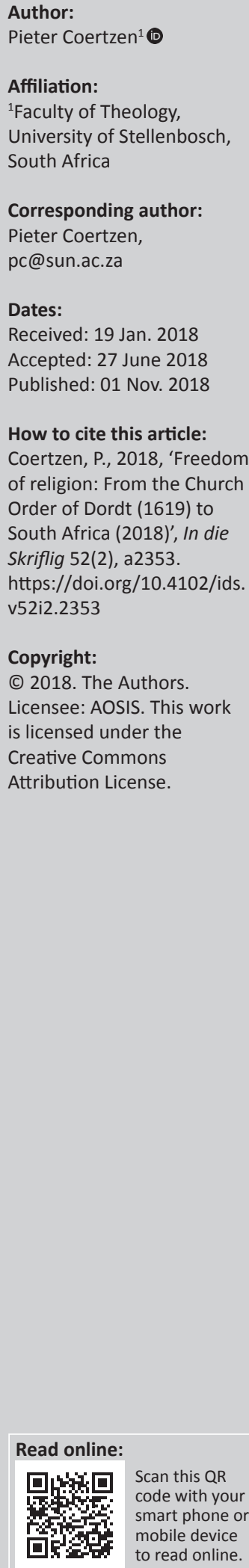

This article is about freedom of religion as an integral part of the Reformation of the 16th century and how it was expressed in the Church Order of Dordt (1619) and later at the Cape of Good Hope under the rule of the Political Council. The article also traces the route of freedom of religion under the rule of the English and after 1910, under the rule of various political parties until the current situation (2018) with a Constitution that guarantees freedom of religion for every person in South Africa, and The South African Charter of Religious Rights and Freedoms.

\section{Introduction}

Without fear of contradiction, it can be said that the Reformation of the 16th century was about freedom of religion - the right of Christian believers to differ from and to criticise the official teaching of the Roman Catholic Church, to express their views and to form a new church, and to express their new faith identity. It is very significant that one of Martin Luther's so-called three main Reformation publications (Berkhof \& De Jong 1975:146) was about the freedom of a Christian person. It is said that this publication contains the most direct reference to Luther's big reformational finding, namely that man is saved through faith alone. The fact that this is published under the title of The freedom of a Christian person, of course makes the theme of freedom of religion as a prominent part of the Reformation very obvious. The central research question of this article can be formulated as follows: What form did freedom of religion take on during the time of the Synod of Dordt and especially in the 1619 Church Order of Dordt during the time of the Dutch rule at the Cape, during the time of the English rule at the Cape, after 1910 when the Union of South Africa came into existence and in our own time? Freedom of religion took on different forms in different countries, at different times as shall be seen further on in this article. This, however, does not take away that freedom of religion was very important for the Reformation. Therefore, we constantly need to dwell on freedom of religion in order to determine what freedom of religion really is and what the best way is for freedom of religion to find expression in our own time.

\section{The Church Order of Dordt (1619) in context and meaning The context of church and state relations in the Netherlands in the 16th and 17th centuries}

The fourth National Synod in the Netherlands was held in 1586 in The Hague under difficult military and political conditions. The war against Spain was not going very well and in 1584, Prince William of Orange was assassinated. It became clear that the States-General could not contain the situation. They consulted first with Henry III of France and then with Queen Elizabeth I of England to take over the sovereignty in the Netherlands. Both refused, but Elizabeth sent Robert Dudley, the Earl of Leicester, together with 5000 troops to the Netherlands. According to Williston Walker (1970:386), his rule was a failure and he returned to England in 1587.

Leicester, however, did support the Reformed Church in its quest for greater independence from the authorities (De Jong 1972:168) and he clearly realised that a well-ordered church was necessary to cope with the variety of viewpoints which threatened to tear the church apart. It was on his instruction that a National Synod met in The Hague from 20 June to 01 August 1586 after putting pressure on various provincial states to support the calling of a National Synod (Pont 1981:158-159).

After the departure of the Earl of Leicester from the Netherlands in 1587, the relationship between state and church in the Netherlands got worse. In the Province of Holland, the rulers were viewed as wanting to rule over the church, while the rulers were wary that the church wanted too much 
say in political matters. By the end of 1589 the rulers in the Province of Utrecht, for instance removed all reformed ministers and decided that, in future, they would call only 'peace loving ministers'. In the rural areas of Utrecht, the owner of a church had the right to take to the authorities the name of a minister of his choice for approval, while in the cities, it was seen as the right of the magistrate to appoint a minister. No classes were established and no Provincial Synod could be held (De Jong 1972:171ff.). The authorities were bent on keeping church discipline in their hands (Bakhuizen van den Brink \& Dankbaar 1967:276). What in fact was happening, was that the system of church-state relations, dating from the time of Constantine and as it was also worded in article 36 of the Dutch Confession of Faith and being asserted in the Netherlands, the state protected the church, but also controlled it.

Between 1586 and 1619, the Dutch society became ever more divided between on the one hand, the strict Calvinists (preciezen, also called kerkelijken) who stood for a strict interpretation of the confession and were against interference by the state in matters of the church, and on the other hand, the more tolerant rekkelijken (also called the politieken) who were afraid of confessional coercion by the church and desired the protection of the authorities against such a possibility (Bakhuizen van den Brink \& Dankbaar 1967:276). Casper Coolhaes (1534-1615) was a supporter of the latter. He was removed as minister in Leiden for siding with the authorities and because of his heterodox views. In society itself, various humanistic traditions dating from Erasmus of Rotterdam, could be found, and Anabaptism was widespread. These expressed themselves in an emphasis on the more practical aspects of religion, in a disinclination towards sharp creedal definitions and a more tolerant attitude such as could be found, for example in the ideas of Dirck Coornhert (1522-1590). These ideas came to their fullest expression in the work of Jacobus Arminius (1560-1609) and his followers. Regarding predestination, Arminius accentuated the responsibility and free will of humans according to which God chooses a person out of grace for the sake of Christ, but in this he takes into account the faith of the person which he foresaw (Bakhuizen van den Brink 1960:277-280).

A conflict sprang up between Arminius and Franz Gomarus, his Calvinist colleague at the University of Leiden, over the doctrine of predestination (Walker 1970:399). Gomarus maintained that God had decided from eternity whom to elect and whom to reject according to his will. He taught that even the faith through which a person is saved, is a free gift of God's grace for the elect (Bakhuizen van den Brink 1960:287-288). Soon the two colleagues were in a bitter conflict that affected not only the country, but also the international reformed world. At this time, both parties insisted on a general or national synod to resolve the matter. Gomarus and his followers wanted a synod to decide in their favour, while the followers of Arminius saw a synod as a place where a conference could be held about the confession which could lead to a revision of the confession.
After the death of Arminius in 1609, Johannes Uytenbogaert (1557-1644) and Simon Episcopius (1583-1643) became the leaders of the Arminians. The 'Arminian' views were systematised, opposing the emphasis on minutiae of doctrine and viewing Christianity primarily as a force for moral transformation.

In 1610, at the insistence of the eminent Dutch statesman from the states of Holland and a supporter of religious tolerance, Johan van Oldenbarneveldt (1547-1619), Uytenbogaert, Episcopius and 41 of their sympathisers drew up a statement of their faith called the 'Remonstrance' [Declaration], from which the party gained the name 'Remonstrants'. Van Oldenbarneveldt did not deem a national synod necessary and was of the opinion that the matter could be settled in the Province of Holland. The Remonstrance was directed to the states of Holland (Nauta 1949:52). The document was a summary of Arminius' views, a plea for a revision of the confession of faith and the Catechism, and an expression of their view that the states had the highest authority over ecclesiastical matters (Bakhuizen van den Brink 1960: 290-293). Uytenbogaert also stated his opinion in a separate publication that the government stood higher than all ecclesiastical gatherings, and as such, should have the final say in ecclesiastical matters (Blei 2006:30).

The Calvinistic opposition, under the leadership of people such as Petrus Plancius in Amsterdam, Festus Hommius in Leiden and Sybrandus Lubbertus (a professor in Franeker), issued a Contra-Remonstrance on 11 March 1611 in which they opposed the views of the Remonstrants, rejected talk of a review of the confession and advocated the independence of the church to decide for itself on matters of dogma and doctrine. They recognised the authority of the government regarding matters external to the church, but denied that it had the authority to express itself in ecclesiastical differences regarding doctrine (Bakhuizen van den Brink 1960:293-300; Bakhuizen van den Brink \& Dankbaar 1967:277; Nauta 1949:53).

In more than one city, the authorities favoured the Remonstrants and made it very difficult for the ContraRemonstrants. In the states of Holland, Provincial Synods had been prohibited since 1608 (Nauta 1949:53-54). On 23 July 1617, Prince Maurits openly attended a worship service of the Contra-Remonstrants in The Hague and thereby showing his support for them (Nauta 1949:54). The conflict soon affected the whole of the Netherlands as it took on political dimensions with sharp differences between Prince Maurits of Orange who sided with the Calvinists, and Johan van Oldenbarneveldt and Hugo Grotius who sided with the Arminians. In political terms, Prince Maurits sided with the so-called 'national party', while van Oldenbarneveldt and Grotius were the leaders of the 'states rights' party which also included wealthy merchants. At that point in time, the 'national party' still desired a national synod to decide the controversy, while van Oldenbarneveldt and the provinces of Holland (excluding Amsterdam) and Utrecht held that each 
province should decide its own religious affairs. In 1617, the states of Holland declared themselves against a national synod through the so-called 'Scherpe Resolutie' and took steps to maintain order in the cities through the deployment of city troops (Bakhuizen van den Brink \& Dankbaar 1967:278). Realising the danger of this event for the union, Prince Maurits obtained the support of the States-General, and through a coup d'etat in July 1618, overthrew the 'states rights' party. Van Oldenbarneveldt was beheaded on 13 May 1619 and Grotius was condemned to life imprisonment in Loevestein. He escaped in 1621 . The way was now open for the States-General to call the National Synod of Dordt of 1618-1619. The Contra-Remonstrants were assured of victory at the synod, but in the end, it meant that future meetings of a national synod would also be subject to permission from the authorities - permission which was not to be granted for nearly 200 years, severely hampering the development of the Reformed Church in the Netherlands. In July 1619, the StatesGeneral approved the Canons of Dordt. The government then also cooperated in the execution of disciplinary measures against preachers of the Remonstrant party who refused to resign as ministers. Those to whom the measures applied, were banished from the country (Blei 2006:33). After the death of Prince Maurits in 1625, they returned and in 1634 established themselves in Amsterdam in a theological seminary with Episcopius as professor (Nauta 1949:56). They did not receive official recognition until 1795 (Bakhuizen van den Brink \& Dankbaar 1967:278; Walker 1970:400).

\section{The ecclesiastical context of the Church Order of Dordt}

To bring the various dispersed Dutch churches together in the 16th century, the Convent of Wezel was organised in 1568. In our time, the question is asked by some whether the Convent of Wezel ever took place (see Jesse Spohnholz 2017). For this article, it is not necessary to go deeper into this question. On the evidence, which we have, we can accept that the convent did take place. The meeting is best understood as an informal discussion forum between refugee Dutch ministers and elders from various places in Europe and England. At the meeting, they formulated, in accord with the Ordonnances Ecclésiastiques of Geneva, certain stipulations for a Calvinistic Church Order (Bakhuizen van den Brink \& Dankbaar 1967:273). The Convent of Wezel was followed by the first National Synod of the Netherlands (Haitjema 1951:23; Pont 1981:93) in the northern German city of Emden (1571), because there was a Dutch refugee congregation. At this synod, a first church order for the reformed churches in the Netherlands was drawn up. At the time, it was not called a church order, but is indicated as the Acts of the Dutch churches under the cross and dispersed in Germany and East-Friesland (Pont 1981:103). These Acts of Emden founded the Dutch Reformed Church in the Netherlands, ready to enter the Netherlands as soon as that country was free from Spanish oppression.

The character of that church is seen by some as clearly Calvinistic. Others characterise it as Presbyterian or anti-hierarchical (Bakhuizen van den Brink \& Dankbaar 1967:273). Leo Koffeman (2009:71) sees it as presbyterialsynodical, meaning that the responsibility for leadership in the church rests with the church councils - the local churches are the presbyterium, while the broader meetings are the expression of the synodical character of this form of church government. The theology behind this form of church government is, according to Koffeman (2009:72), the collegial exercise of authority by the offices in the church. The very first article of Emden is extremely important if we want to understand the reformed character of Reformed Church government and eventually the nature of the Church Order of Dordt. The way it is put in the Church Order of Emden reads:

No church shall lord over another church; no minister of the word over another minister, no elder over another elder, neither any deacon over another and everyone will be on guard for any suspicion and longing to lord.

On the face of it, this article forbids any lording of churches or offices over each other, but behind this wording lies the most fundamental principle of the Reformation, namely that Jesus Christ is the only Lord and Head of the church and none other. It is the insight of John Calvin and the wording of the Belgic Confession (2000 [1561], art. 30) - 'We believe that true church ought to governed according to the spiritual order that our Lord taught us in his Word' - that lie behind Emden's wording (Bakhuizen van den Brink 1960:192; Inst. 1.317; Belgic Confession, article 30; Jonker 1965:12; Pont 1981:110). The Acts of Emden (Acta of handelingen der verzameling van de Nederlandse kerken onder de kruiszitten, en in Duitsland en Oost-Friesland verstrooid zijn, gehouden te Emden die 4e Oktobber 1571: art 2 in Pont 1981) also required that ministers subscribe to either the Dutch or the French confession of faith, while either the Genevan or the Heidelberg Catechism could be used for teaching purposes (Acta 1571: art. 5 in Pont 1981).

The National Synod of Dordrecht of 1618-1619 took place at the Kloveniersdoelen in Dordrecht (De Jong 1972:189) in two phases. The first phase started on 13 May 1619 and ended on 29 May of the same year. In total, the synod consisted of 180 sessions (Pont 1981:168). For the first phase, the StatesGeneral invited 23 theologians as representatives from Great Brittain, Nassau, Wetterau, the Palatine, Hesse, Bremen, Geneva and Switzerland; the representative from Scotland only joined the synod on 20 December (Synod of Dordrecht (1618-1619) 1987:10-11, 139; Berkhof \& De Jong 1975:205). Representatives from the French church were also invited to attend, but were refused permission by the French authorities. The government was represented by no less than 18 political commissioners. In addition, present at the synod were five Dutch theologians, 37 ministers and 19 elders. Among those ministers and elders were three Remonstrants. The chairperson of the synod was Johannes Bogerman and the scribe was Festus Hommius (Berkhof \& De Jong 1975:205). On 06 December, a group of Remonstrant theologians was summoned to appear before the synod. They were joined by 
the three representatives who were already at the synod. When the Remonstrants continuously questioned the procedure and legitimacy of the synod they were dismissed by Bogerman on 14 January 1619. A few days later, the procedure was approved by governmental decree. The three Remonstrants representatives at the synod also left in solidarity with their fellow party members (Bakhuizen van den Brink \& Dankbaar 1967:278; Blei 2006:31). On 06 May 1619 , the Canons (doctrinal rules) of Dordt were announced. They became the third confessional formula of the Reformed Church in the Netherlands alongside the Belgic Confession (2000 [1561]) and the Heidelberg Catechism (1563). In five chapters the Canons consider 'divine election and rejection', 'the death of Christ and salvation through Him', 'human depravity', 'conversion to God' and 'the perseverance of the saints' (cf. Blei 2006:32).

In the second phase of the synod, attention was given to matters such as the church order and also the translation of the Bible. The church order was a revision of the Church Order of The Hague (1586). In broad lines the church order remained unchanged and the typical reformed characteristics, which were already present at the Synod of Emden, remained: the offices in the church, the tasks and authority of ecclesiastical assemblies at the various levels, confessional matters, the administration of the sacraments and Sunday worship, oversight and discipline in doctrine, and church members and office bearers' way of life. The Church Order of Dordt concludes with the prescription with which the Church Order of Emden had begun: 'No church shall have any authority over other churches, no minister over other ministers, no elder or deacon over other elders or deacons' (art. 84). Article 30, on the functions of the various levels of assemblies, had already been formulated by the Synod of Dordt of 1578 (Blei 2006:33).

Nauta (1949:57) remarks that, at Dordrecht, the ContraRemonstrants gained a convincing victory over the Remonstrants, but on one point they could not score and that was on the authority of the state over church matters. It can also be said that in matters of freedom of religion, the state maintained its authority over churches. In the calling of a minister it was determined that a consultation with the local Christian government would be required. Moreover, after the choice had been made, subsequent approval had to be obtained not only from the members of the congregation, but first from the same government (art. 4). The government also obtained the right to have one or two of its representatives on church councils 'to listen and to share in the deliberations of matters on the agenda' (art. 37). The governmental representatives of course had to be members of the congregation. A new article in the church order was article 28 which dealt with the relation of the church to the government. The first part of article 28 stated that it was the office of a Christian government to advance and protect the ministry of the church. The second part of the article introduced a new emphasis into a Reformed Church order whereby the vocation of the church in relation to the government was described as consisting of two matters. Firstly, it was the duty of all ministers, elders and deacons to zealously and faithfully inculcate in the entire congregation obedience, love and honour owed to the magistrates (rulers). Secondly, the ministers, elders and deacons with becoming respect (and correspondence) had to seek to waken and maintain the favour of the government towards the churches so that all second-guessing and mistrust could be avoided and concord be maintained for the well-being of the churches (Blei 2006:33-36).

\section{Preliminary conclusion}

With regard to both the political and the ecclesiastical situations in the Netherlands, we find that the relationship between church and state played an exceptional role. During the first part of the Synod of Dordt of 1618-1619 - when doctrinal matters were on the table - the political situation made it possible for the synod to be called. The States-General invited the international representatives, they ratified the decisions of synod, and they took disciplinary measures against the Remonstrants. We have also seen the extent to which the church was willing to write measures into the Church Order of Dordt, giving the state very strong control over the church; in other words, impeding their own religious freedom. It was in fact so strong that, after Dordt (1618-1619), it was not possible for the Reformed Church to meet again in a national synod, because the authorities prohibited it.

In terms of the development of religious freedom through the ages up until now, it would entail that any religious institution and church have the right to determine its own confessions, doctrines and ordinances. It also has the right to decide for itself in all matters regarding its doctrines and ordinances, and in accordance with the principles of tolerance, fairness, openness and accountability, to regulate its own internal affairs, including organisational structures and procedures, the ordination, conditions of service, discipline, dismissal of office bearers and members as well as determining of membership requirements. Apart from this, religious freedom also means that churches and religious institutions are recognised and protected as an institution that have authority over their own affairs and towards which the state, through its governing institutions, is responsible for just, constructive and impartial government in the interest of everybody. The state, including the judiciary, must respect the authority of every religious institution over its own affairs, and may not regulate or prescribe matters of doctrine and ordinances (The South African Charter of Religious Rights and Freedoms 2010: art 9.2 \& 9.3).

Measured against the above standards it is clear that there was not much of religious freedom for churches recognised and displayed in the Netherlands during the time of the Synod of Dordt in 1618-1619. In fact, that can be said of all the churches which were present at the Synod of Dordt. The relationship between church and state was very much one where the state protected the church, but, at the same time, also kept the church subjected to the laws and rules it made. 


\section{Freedom of religion in South Africa ${ }^{1}$ Under the Verenigde Oostindische Compagnie (VOC) (Dutch East Indian Company [DEIC]) (1652-1795)}

On 22 August 1650, the VOC, decided that for the sake of greater security and refreshment for their ships, they would start a settlement at the Cape of Good Hope (Vorster 1956:11).

In 1652, Jan van Riebeeck, an official of the VOC together with about 200 Company employees, landed at the Cape to start a refreshment post for the fleets of the Company that passed the Cape on their way to and back from the East (Hanekom 1965:290). Van Riebeeck was a member of the Reformed Church in the Netherlands and the Company he served, had as a condition in its second Charter of 1622, the policy to advance the reformed religion among the peoples of the countries where they did business.

In fact, from 1652 to 1795 the responsibilities for religion and spiritual care of the people of the Cape resided with the Political Council under the leadership of the Commander (Vorster 1956:38). The VOC appointed sick comforters and ministers in the various places. The ministers appointed by the VOC, were not in the first place ministers of the Reformed Church, but officials of the Company who had a rank equal to that of a vice-merchant. The churches in the Netherlands could claim no rights with regard to sick comforters and ministers in the service of the VOC (Boetzelaar van Dubbeldam 1906:119); they were subject to Company officials of higher rank than themselves. The commanders assumed the right to give sick comforters authority to administer baptism. They appointed and dismissed ministers and comforters of the sick. Ministers could receive no instruction from classes in the Netherlands other than those approved by the Lords XVII (see below). In any civil case, they were subject to the authorities of the Company both on sea and on land. At any time, the Lords XVII could recall them without giving reasons. They were allowed to correspond with a classis if the classis were involved in a matter, but the classis served only an advisory role.

The Charter awarded to the VOC on 22 December 1622 by the States-General, gave the VOC Board - consisting of 17 administrators and therefore known as the 'Lords XVII' - full sovereignty with regard to navigation, trade and warfare in the areas to which they expanded, but also obliged them to conserve the 'public faith' (Vorster 1956:11). In practice, this meant that the VOC or the Lords XVII also had full control over church matters in the places where they traded. Before describing what this meant in practice, the question about which church order had authority at the Cape, needs our attention.

The Church Order of Van Diemen had been accepted in 1643 for the East Indies. It was done by Van Diemen without any consultation with the fatherland. This church order

1 Compare Coertzen (2008:115-139); Potgieter (1952:24-90); Wegener (1965). determined that permission of the government was necessary for nearly any action by the churches, including the election of elders. The church in East India was completely controlled by the government (Boetzelaar van Dubbeldam 1906:139) and thereby effectively lost its freedom. Vorster makes a very strong case that the Church Order of Van Diemen was never used at the Cape of Good Hope and that it was rather the Church Order of Dordt of 1619 that guided the life of the church at the Cape. In 1710, J. Martens, a visiting minister, suggested in a meeting with the Governor and Reverent d'Ailly that the Church Order of Batavia (Van Diemen) might be used at the Cape, as Batavia was geographically much nearer to the Cape - at least until further clarity was obtained (Spoelstra 1907:610). To this consideration Reverent d'Ailly responded, 'The Church Order can easily be found in the Acts and Post-acts of the Synod of Dordt - in exceptional cases they could however consult with the foreign brothers' (Spoelstra 1907:612). Upon this, the Political Council at the Cape decided on 10 March 1710 to ask the Lords XVII which church order must be used at the Cape: the one of the fatherland or the one of Batavia. On 30 March 1710, a letter was written to the Lords XVII and on 08 October 1710 they recognised receipt of the letter. The Lords XVII postponed their answer and eventually never responded. From the questions asked and the information given, it is clear that the church at the Cape was satisfied to observe the Church Order of Dordt of 1619 and that they did not really need anything else (Vorster 1956:83). It must, however, be clearly understood that the Church Order of Dordt was never officially accepted as a church order for the church at the Cape. The position was very similar to the situation in the Netherlands where the Church Order of Dordt was neither officially accepted by the States-General nor by all the states of the union or by all the provincial synods. We know that the Classis of Amsterdam, which was responsible for all the overseas churches, did follow the Church Order of Dordt. Apart from the abovementioned request, there are also other indications in the life of the church at the Cape that they followed the Church Order of Dordt even though it was not officially accepted by the States-General, all the provinces in the Netherlands and also not in all the synodical areas (Bakhuizen van den Brink \& Dankbaar 1967:278). It is clear that the articles of Dordt were followed at the Cape with regard to preaching from the Catechism, house visitation before Holy Communion, and the subscription of teachers to the Confessions of Faith. When in 1743 there was the attempt to introduce a combined meeting of the different church councils at the Cape, it was the Church Order of Dordt that guided the meetings from 1745 to 1759 (Van der Watt 1976:43-44).

However, in spite of all these indications that the church at the Cape considered the Church Order of Dordt, the facts remain that it was never officially accepted at the Cape and that the church was subjected to the rule of the VOC in and through the Political Council. The VOC protected the reformed religion in the areas where they worked, but they also clearly controlled the Reformed Church - just as the authorities in the Netherlands both protected and 
controlled the Reformed Church. Confessionally, this kind of church-state relationship goes back to article 36 of the Dutch Confession of Faith, while historically, it goes back to the time of Constantine when the Christian church received official recognition from the state, but at the same time was also controlled by the state (Nederlandse Geloofsbelydenis 1988).

On 28 November 1689, the Political Council refused the request of the French refugees to install their own church council in Drakenstein (Resolutie Politieke Raad). When the local churches constituted a combined meeting between them, they had in mind a structure equal to a classis. When they informed the Classis of Amsterdam of their achievement, they received praise and blessings. The Classis of Amsterdam did, however, advise them not to call the combined meeting a classis, but rather a 'coetus' or a 'convention'. The reason being that they could not perform all the duties of a classis such as the examination of candidates and ministers for the ministry or the appointment and installation of ministers. In answer to this, the churches at the Cape decided to call their meeting a 'combined meeting'. In practice it performed the duties of a classis. In constituting the meeting they followed the prescriptions of the Church Order of Dordt and on their agenda they treated all the matters usually found on an agenda of a classis meeting. The combined meeting also decided to draw up bylaws for church visitation. In 1759 the combined meeting was suddenly prohibited by the Political Council at the Cape. The reasons they gave were that the costs for the meeting were too high and that the meeting did not restrict itself to its purpose (Van der Watt 1976:38). It was clearly an attempt by the Political Council to keep the church in a state of subordination. This decision had a serious impact on the development of the church in South Africa which was set back until at least 1824 when the first synod at the Cape met in Cape Town.

About the situation in the 18th century, McCall Theal, as quoted by Vorster (1956:39), writes: 'The Church was in one sense merely an engine of the state, and was always and in every sense subordinate to the Council of Polity.' Many more examples of the Political Council, controlling ecclesiastical matters, can be cited in addition to the matters mentioned above (Vorster 1956:39-43).

All of this attests to the fact that, between the years 1652 and 1795, the Political Council at the Cape had a typically Constantinian approach towards the church in South Africa: one of not merely protecting the church, but also controlling it just as was the case in the Netherlands. The church could not say that it had the religious freedom to conduct its own affairs.

\section{After 1795}

After 1795, the rule of the VOC at the Cape ended. It was followed by the first British occupation from 1795 to 1803 . That was followed by the Batavian rule under Governor de Mist, and from 1806 on, English colonial rule. Under all these rulers the same approach with regard to the church was followed. The rulers protected the church, but they also controlled the church (Die Kerkorde van De Mist [25 Julie 1804] in Dreyer 1936).

\section{The Synod of 1824}

The decision of the Political Council in 1759 to stop the meetings of the 'combined meeting' of churches, clearly hampered the normal development of the church at the Cape, because it was only in 1824 that the church received permission from the then English authorities to hold a synod. In 1822, the three ministers of the church in Cape Town, Abraham Faure, Jan Christoffel Berrange and Johann Heinrich von Manger, wrote a letter to the Governor, asking his permission to call a meeting of a synod or a general meeting according to the terms of the church order drawn up by De Mist (art. 46) in 1804. Among the reasons, they noted, were that church councils and synods are the ways by which Presbyterian churches are governed. Further, it would help to overcome differences, advance religious education and promote unity among the different ministers. Following the loss of support from the classes and synods in the Netherlands, it was argued that the ministers were more or less left to themselves and church councils had no 'higher' body to join. Also, the numbers of the Dutch Reformed Church were growing and an increasing number of previously-unknown religious bodies, which could disrupt the existing order, were making their appearance. Permission was granted and the first synod of the Dutch Reformed Church met on 02 November 1824. In drawing up articles for the management of the church, the meeting took as guideline the Algemeen Reglement [General Regulations] of the Reformed (Hervormde) Church in the Netherlands. However, when the Praeses and Scribe wrote to the Governor after the meeting, they requested that the General Church Order of the National Synod of Dordrecht also be printed by the government press, 'being a fundamental piece of all our regulations to which each of us is held' (als zijnde een fundamenteel stuk van alle de Regulatiën onzer Kerk, waaraan elk onzer gehouden is) (Moorrees 1937:554). Thus, it is clear that in 1824, the Church Order of Dordt still played an important role in the minds of those gathered at the Synod of 1824.

\section{Ordinance 7 of 1843}

In 1843, the Church Ordinance of De Mist, to which the churches at the Cape still had to adhere, was replaced by the Ordinance Number Seven of 1843. This ordinance supposedly made the church more free from control by the government in that political commissioners no longer took seats in church meetings and the church received the power to regulate its own internal affairs. The ordinance was presented under the heading of 'The Separation of Church and State Petition'. Yet, in practice, the church remained subject to government in so far as the government still controlled the church through the so-called 'power of the purse' and the privilege of presenting ministers to congregations. Furthermore, the ordinance restricted the church with regard to its faith identity, its 
organisation, its competence and its geographical limits (Kleynhans 1973:80-84). It was generally accepted that Ordinance Number Seven of 1843 severely restricted the freedom of the church (Van der Watt 1980:44-46).

The Dutch Reformed Church in South Africa (Cape Province) eventually decided on 21 October 1957 to ask the government to revoke Ordinance Number Seven of 1843:

The Dutch Reformed Church in South Africa declares and confirms its historical view that this church as an body had an independent existence in its own competence even though always subjected to the articles of law applicable to the church. Since the existence of the church is not dependent on the articles of law, Synod, given the legal advice which was obtained, mandates the Moderature to approach the authorities to revoke Ordinance Number Seven of 1843. (Kleynhans 1973:95)

\section{February 1859}

One of the results of the Great Trek to the northern parts of South Africa during the 3rd decade of the 19th century and of providing pastoral care to the people there, was the eventual establishment of two other reformed churches in South Africa: the Netherlands Reformed Church (Nederduitsche Hervormde Kerk) on 01 November 1853, and the Reformed Churches in South Africa on 11 February 1859. On 12 January 1859,12 persons signed a declaration of secession which they handed to the meeting of the general council of the church in the Transvaal. In the declaration they indicated that they wished to withdraw from the existing church community and to exist in future as a free Reformed Church according to the teaching, discipline and ministry of the fathers as revealed at Dordt in 1618. They also indicated that they would apply the Church Order of Dordt in accordance with the circumstances in which they lived (Van der Watt 1977:67, 84). Today this church is known as the Reformed Churches in South Africa. To this day its confessional base is still the three Formulae of Unity and its accepted church order is still the Church Order of Dordt - as amended for South African conditions (Vorster 2003:2-9; 2008:383). The church retained article 28 of the Church Order of Dordt, although with a modified wording.

\section{8}

In 1948, the Nationalist Party came into power and very soon started to enforce its policy of apartheid on the whole of the country, including the churches. Not all churches accepted the policies of the government and some continued to resist it. Of that time it cannot be said there was no tolerance of different faith convictions in the country or that churches did not have the freedom, for instance to determine their own church orders, but all the while the government was trying to control the churches through its policies. However, it must also be said that in many cases, Afrikaans-speaking churches not only subscribed to the policies of the government, but also encouraged them. Even if there were certain freedoms for churches, the Constantinian approach of protect-andcontrol remained the main characteristic of church-state relations until 1994.

\section{November-December 1959}

In May 1959 the Council of Dutch Reformed Churches, meeting in Bloemfontein, accepted a new proposed church order for the government of the Dutch Reformed Church. Willie Jonker comments that this concept church order would not only serve as a basis for the organic unification of the Dutch Reformed Church in the different provinces of the country, but that it would also serve to strengthen and establish the reformed character of the church (Jonker 1959:795), enabling the church to be governed by the Word of God through its church order. He then points out that it was the explicit intention of the drafting commission that the new church order be linked as closely as possible to the Church Order of Dordt. He (Jonker 1959) writes:

The church order of Dordt is without doubt the best and purest historical formulation and summary of the scriptural principles on which Reformed Church government rests in spite of a few articles which could be formulated in another way, due to the changes in time (p. 796).

He continues by saying that the Dutch Reformed Church, in spite of not having the Church Order of Dordt as an official document of the church, i never lost the spirit and main principles of the Church Order of Dordt (Jonker 1959:796). The new provisional church order that was approved, tried to stay as closely as possible to Dordt in its different chapters and sometimes even in the way in which articles were formulated (Jonker 1959:796). It must of course also be kept in mind that the new church order of the reformed churches in the Netherlands (1957-1959) also had a big influence on the new church order of the Dutch Reformed Church. Nevertheless, it can be said that the Church Order of Dordt, with its reformed principles, formed and still forms the foundation of the church order of the Dutch Reformed Church. Jonker mentions a few points where he thought the church order of the Dutch Reformed Church could still be brought closer to the principles of Dordt, for example there should not be a permanent moderature following the meeting of synod (Jonker 1959:835). It is interesting that, at the meeting of the General Synod in October 2011, exactly this change was approved in the church order, showing that the Dutch Reformed Church is continuously looking at its church order to bring it in line with reformed principles of church government.

It is interesting to read in the church orders of the church from 1962 to 1994 how the church always affirmed its right to freedom of religion over and against the state, although, at the same time, it also acknowledged the protection of the church by the state. In the official publication Church and Society (1990) the Church states the following in article 301:

The principle of religious freedom must be maintained at all times. This means that the government must be impartial to all churches and religions, that scope must be given in which the church may continue with its work without government interference and that no one will be discriminated against on account of their religious convictions. (art. 301) 


\section{New developments in South Africa after 1994 - constitutionally guaranteed freedom of religion ${ }^{2}$}

In 1994-1996, a new Constitution for South Africa (Republic of South Africa 1996) was approved. With the new Constitution, a new era for church-state relations in South Africa started. Actually, not only new church-state relations started, but also new relations between the state and religions as well as between religion and religion. In the Constitution, religion (churches) is dealt with in article 9(3) where it is stated that there can be no discrimination against a person on grounds of religion. Article 31 says that persons, belonging to a religious community, have the right to enjoy and practice their religion, form, join and maintain religious associations and other organs of society. Article 185 provides for a 'Commission for the Promotion and Protection of the Rights of Cultural, Religious and Linguistic Communities'. Very important for religions in South Africa is article 15 of the Constitution (Republic of South Africa 1996) that states:

(1) Everyone has the right to freedom of conscience, religion, thought, belief and opinion.

(2) Religious observances may be conducted at state-aided institutions, provided that (a) those observances follow the rules made by the appropriate public authorities; (b) they are conducted on an equitable basis and (c) attendance is free and voluntary.

The third part of article 15 allows for marriages in South Africa to be concluded under any tradition or system of religious, personal or family law (Republic of South Africa 1996:15). Also important for religions is the fact that article 7(2) of the Constitution (Republic of South Africa 1996) reads that 'The state must respect, protect, promote and fulfil the rights in the Bill of Rights.' All of these are very strong securities and opportunities for religions in South Africa since 1994-1996. Added to all of this, there is also article 234 of the Constitution which, in order to deepen the culture of democracy, allows for Parliament to adopt Charters of Rights consistent with the provisions of the Constitution. Religions in South Africa have taken up this challenge and in the past few years have developed a South African Charter of Religious Rights and Freedoms which they endorsed without giving Parliament the final say over the Charter. The Charter comes from the religions and in the final instance remains their property. In the Charter, the religions in South Africa lay out what they understand under the term freedom of religion. The Dutch Reformed Church has already decided to make the Charter part of its official documentation through inclusion in the Church Order Book of the church (Nederduitse Gereformeerde Kerk 2011:286

The relationship between church or religion and state in South Africa can be described as one of amicable cooperation. Article 15 of the Constitution (Republic of South Africa 1996) reads 'Everyone has the right to freedom of 2.Compare Witte (1996:XVII-XXXV; 2000). conscience, religion, thought belief and opinion.' Article 234 of the Constitution allows that, in order to deepen the culture of democracy established by the Constitution, Parliament may adopt Charters of Rights consistent with the provisions of the Constitution. Article 181 of the Constitution provides for various state institutions to strengthen constitutional democracy in SA, the so-called Chapter nine institutions. Among them, there is The Commission for the Promotion and Protection of the Rights of Cultural, Religious and Linguistic Communities also called the CRL-Rights Commission (Republic of South Africa 1996, sections 181 and 185).

Given these provisions in the Constitution, academics, theologians, legal scholars (both national and international) and religious leaders worked to formulate a South African Charter of Religious Rights and Freedoms in order to explain what freedom of religion entails for everyone in South Africa. On 21 October 2010, representatives of about 15 million believers in SA endorsed a South African Charter of Religious Rights and Freedoms. Since 2010, the number of persons endorsing the Charter has grown to about 25 million people. The CRL-Commission has also mentioned the Charter approvingly in Parliament. At a recent Portfolio Committee on the report of the CRL-Commission, more than one religious body referred to the Charter in positive terms. The Charter has also become widely accepted in the South Africa society. The Charter is endorsed by most of the mainline churches as well as charismatic churches, members of the Jewish community, the Muslim community, the Hindu community as well as members of African traditional religion. More times in the recent past these religions have stood together, for instance to ask for religious education in public schools. One of the original endorses of the Charter was the CRL-Rights Commission.

The Charter spells out in greater detail wat religious freedom means for the religious people and religious bodies in South Africa. In other words, what the religious rights and freedoms are that can be claimed in South Africa. The Charter also plays a very important role in the protection of people's religious rights and freedoms. It is about:

- The right to belief and the right to what you may belief or not belief (art. 1).

- The right not to be forced about your belief (art. 2).

- The right to impartiality and protection of the state in respect of religion (art. 3).

- Every person's right to private or public, individual or joint observance or exercise of their religion (art. 4).

- The right of persons to maintain traditions and systems of religious personal, matrimonial and family law that is not inconsistent with the Constitution (art. 5).

- The right of every person to freedom of expression in respect of religion (art. 6).

- The right of every person to be educated or to educate their children or have them educated in accordance with religious or philosophical convictions (art. 7). 
- The right of every person to receive and provide religious education, training and instruction. The state may subsidise such education, training and instruction (art. 8).

- The right to institutional freedom - the right of every religion to determine its own confessions, doctrines and ordinances and to regulate its own affairs (art. 9). Every religious institution is subject to the law of the land. A religious institution must be able to justify any nonobservance of a law resulting from the exercise of the rights in the Charter (art. 9).

- The right of all religions in South Africa who qualifies as a juristic person to receive tax, charitable and other benefits from the state (art. 10).

- The right of every religious person to solicit, receive, manage, allocate and spend voluntary financial and other forms of support and contributions - the confidentiality of such support and contributions must be respected (art. 11).

- Every religious person has the right to conduct relief, upliftment, social justice, developmental, charity and welfare work in the community and also to establish, maintain and contribute to charity and welfare associations, and solicit, manage, distribute and spend funds for this purpose (art. 12).

After the endorsement of the Charter a South African Council for the Promotion and Protection of Religious Rights and Freedoms (SACRRF or just CRRF) was elected to guard over and protect the Charter of Religious Rights and Freedoms. In August 2015, explanatory notes on the Charter were approved of as an aid to understand the Charter and its implications (The South African Charter of Religious Rights and Freedoms and Explanatory Notes 2015).

\section{Conclusion}

From 1652 to 1994, the state authorities in South Africa always had, to a greater or lesser degree, a determining say in the affairs, first of the Dutch Reformed Church, and later in the affairs of all churches in South Africa, although not always with the co-operation of all the churches. It was a typical Constantinian situation whereby the state protected churches, but at the same time, also tries to control them. Understanding this relationship between state and church in South Africa, sheds a completely new light on the accusation often made that it was the church(es) through a theocratic relationship with the state that were responsible for the ideology and practice of Apartheid. It was not theocracy where the policies of the church indeed control society - but rather the Constantinian relationship between church and state that was largely responsible for the state ideology of apartheid. It must, however, also be recognised that the churches often asked the government for apartheid measures to be taken.

The new (since 1994 and 1996) situation in South Africa for religions brought about most definite freedoms not only for Christian churches, but also for all religions. At the same time, it also brought certain obligations. It is of little avail for religions to have constitutional guarantees of freedom of religion and a Charter of Religious Rights and Freedoms spelling out the religious rights religions can claim if the religions themselves do nothing to appropriate and apply those rights. If religions do not claim and use the religious space provided for them in the Constitution and the Charter of Religious Rights and Freedoms, the consequence will be that any right that they claim will be adjudicated in terms of the laws of the land. A religion, for instance cannot limit the rights of employees in labour relations if its own order gives proof that freedom of religion in labour relations has not been appropriated in its own rules. A religion also cannot claim special rights with regard to disciplinary hearings and, for instance limit the rights of the accused with regard to legal representation if it does not show proof that it has used the right to freedom of religion in making sure its disciplinary hearings are done in accordance with its faith identity. All of this makes it very important for churches and religions to ensure that their church orders or rules of order conform to their faith identities. That is what the Church Order of Dordt intended to do with regard to the life of reformed churches. Unfortunately, the relationship between state and church did not always allow for that. Freedom of religion in a constitutional state creates the opportunity for a church or a religion to create its own order as long as it can be shown that the order is based in the faith identity of the church or religion and that limitations on rights of its members are also in conformity with the church's faith identity. Also, for the Dutch Reformed Church there is now the guaranteed freedom to lay down its own rules for matters such as church unification, labour relations, disciplinary actions, theological training, et cetera as matters of fact for the whole life of the church.

\section{Acknowledgements}

This article is a revised version of the article 'Dordt and South Africa. Church and state Relations in the Netherlands and in South Africa' which was published in Allan J. Janssen and Leo Koffeman (eds.), 2011, 'Protestant Church Polity in Changing Contexts 1. Ecclesiological and Historical Contributions', paper presented at the International Conference, Utrecht, The Netherlands, 7-10 November, published in 2014 by Lit Verlag, GmbH \& Co. KG Wien Zweignierderlassung, Zürich and by Lit Verlag, Dr. W. Hopf, Berlin. The focus and presentation of the current article is completely different by focusing on freedom of religion and not on church-state relations as the previous article. A lot of updating has also been done.

\section{Competing interests}

The author declares that he has no financial or personal relationships which may have inappropriately influenced him in writing this article. 


\section{References}

Bakhuizen van den Brink, J.N. (red), 1960, Documenta Reformatoria DI, 1., Teksten uit de Geschiedenis van Kerk en Theologie in de Nederlanden sedert de Hervorming, J.H. Kok, Kampen.

Bakhuizen van den Brink, J.N. \& Dankbaar, W.F., 1967, Handboek der Kerkgeschiedenis, Deel III, (Reformatie en Contra-reformatie), Bert Bakker, Daamen N.V., Den Haag.

Belgic Confession, 2000 [1561], This we believe, thus we confess: The Doctrinal Standards of the Dutch Reformed Church, DRC Synod of Central Africa, CAVA, Harare.

Berkhof, H. \& De Jong, O.J, 1975, Geschiedenis der Kerk, 9e druk, C.F. Callenbach B.V., Nijkerk.

Blei, K., 2006, The Netherlands Reformed Church 1571-2005, transl. A.J. Janssen, William B. Eerdmans Publishing Company, Grand Rapids, MI.

Boetzelaar van Dubbeldam, C.W. Th. B. v., 1906, De Gereformeerde Kerken in Nederland en de Zending in de dagen der Oost-Indische Compagnie, P. den Boer, Utrecht.

Calvyn, J., 1559, Institusie van die Christelike Godsdiens, vert. H.W. Simpson, Nasionale Media, Potchefstroom.

Church and society, 1990, A testimony of the Dutch Reformed Church, approved by the General Synod of the Dutch Reformed Church, NG Sendingpers, Bloemfontein

Coertzen, P., 2008, 'Freedom of Religion - Then and now', Studia Historiae Ecclesiasticae, 29(2), 115-139.

De Jong, O., 1972, Nederlandse Kerkgeschiedenis, G.F. Callenbach N.V., Nijkerk.

Dreyer, A., 1936, Boustowwe vir die Geskiedenis van die Nederduits-Gereformeerde Kerke in Suid-Afrika, Deel III, 1804-1836, uitgegee deur die Jaarboekkommissie van die Raad van die Nederduits-Gereformeerde Kerke in Suid Afrika, Nasionale Pers Beperk, Kaapstad.

Haitjema, Th. L., 1951, Nederlands Hervormd Kerkrecht, G.F. Callenbach N.V., Nijkerk.

Hanekom, T.N., 1965, Afrika van Suid tot Noord, in G.S. Wegener (red.), Die Lewende Kerk: Afrikaanse uitgawe geredigeer en aangevul deur T.N. Hanekom, Human \& Rousseau, Kaapstad.

Heidelberg Catechism, 1563, in Beeke, J. \& Ferguson, S.B., 1999, Reformed Confessions harmonized with an annotated bibliography of Reformed doctrinal works, Baker Books, Grand Rapids, MI.

Inst. see Calvyn 1559

Jonker, W.D., 1959, 'Die Nuwe Kerkorde dl. I, II \& III', Die Kerkbode, 18 November, bl. 759-796, 800; Die Kerkbode 25 November, bl. 835-837; Die Kerkbode, 2 Desember, bl. 870-871, 883

Jonker, W.D., 1965, Om die regering van Christus in sy kerk, Mededelings van die Universiteit van Suid-Afrika, Pretoria.

Kleynhans, E.P.J., 1973, 'Die kerkregtelike ontwikkeling van die Nederduitse Gereformeerde Kerk in Suid-Afrika 1795 - 1962: 'n Kerkhistories-kerkregtelike studie', Phd-proefskrif, Universiteit van Stellenbosch, Stellenbosch.

Koffeman, L.J., 2009, Het Goed Recht van de Kerk: Een theologische inleiding op het kerkrecht, Kok, Kampen.

Moorrees, A., 1937, Die Nederduitse Gereformeerde Kerk in Suid-Afrika 1652-1873, S.A. Bybelvereniging, Kaapstad.

Nauta, D., 1949, Het Calvinisme in Nederland. T. Wever, Franeker.
Nederduitse Gereformeerde Kerk, 2011, Agenda vir die veertiende vergadering van die Algemene Sinode van die Nederduitse Gereformeerde Kerk, Birchwood konferensiesentrum, Boksburg, 10-14 Oktober.

Nederlandse Geloofsbelydenis, 1988, Handboek vir die erediens van die Nederduitse Gereformeerde Kerk, NG Kerk-Uitgewers, Kaapstad.

Pont, A.D., 1981, Die historiese agtergronde van ons kerklike reg, deel 1, HAUM, Pretoria, Kaapstad.

Potgieter, F.J.M., 1952, 'Ons Kerk in Kaapland', in T.N. Hanekom (red.), Ons NG Kerk pp. 24-90, NG Kerk-Uitgewers, Kaapstad.

Republic of South Africa, 1996, Constitution of the Republic of South Africa, Act 108 of 1996, Government Printers, Pretoria.

Spoelstra, C., 1907. Bouwstoffen voor de Geschiedenis der Nederduitsche-Gereformeerde Kerken in Zuid-Afrika, Deel II, Hollansch-Afrikaansche Uitgevers-Maatschappij, Amsterdam.

Spohnholz, J., 2017, The Convent of Wesel: The event that never was and the invention of tradition, Cambridge University Press, Cambridge.

Synod of Dordrecht (1618-1619), 1987, Acta of Handelingen der Nationale Synode in de Naam van Onze Heere Jezus Christus Gehouden door autoriteit der Hoogmogende Heren Staten Generaal der Verenigde Nederlanden te Dordrecht in do Jaren 1618 en 1619. Hier zijn ook bij openomen de volledige bordrecht in de Jaren 1618 en 1619. Hier zijn ook bij opgenomen de volledige beoordelingen vederduitse uitgave onder toezicht van J.H. Donner, S.A. van den Hoorn, B.V. Nederduitse uitgave
Houten Den Hertog.

The South African Charter of Religious Rights and Freedoms, 2010, The South African Council for the Protection and Promotion of Religious Rights and Freedoms, Oxford University Press, Cape Town.

The South African Charter of Religious Rights and Freedoms and Explanatory Notes, 2015, The South African Council for the Protection and Promotion of Religious Rights and Freedoms, Oxford University Press, Cape Town.

Van der Watt, P.B., 1976, Die Nederduitse Gereformeerde Kerk 1652-1824, NG Kerkboekhandel, Pretoria.

Van der Watt, P.B., 1977, Die Nederduitse Gereformeerde Kerk 1834-1866, NG Kerkboekhandel, Pretoria.

Van der Watt, P.B., 1980, Die Nederduitse Gereformeerde Kerk 1824-1905, NG Kerkboekhandel, Pretoria.

Vorster, J.D., 1956, Die kerkregtelike ontwikkeling van die Kaapse Kerk onder die Kompanjie 1652 - 1792, Pro Rege-Pers Beperk, Potchefstroom.

Vorster, J.M., 2003, An introduction to reformed church polity, Potchefstroom Theological Publications, Potchefstroom.

Vorster, J.M., 2008, 'Gereformeerde Kerke in Suid-Afrika (GKSA)', in F. Gaum, A. Boesak \& W. Botha (reds.), Christelike Kern-Ensiklopedie, p. 383, Lux Verbi.BM \& Bybelkor, Wellington.

Walker, W., 1970, A history of the Christian church, T\&T Clark, Edinburgh.

Wegener, G. S., 1965, Die Lewende Kerk, (Afrikaanse uitgawe geredigeer en aangevu deur T.N. Hanekom), Human \& Rousseau, Kaapstad.

Witte, J., 1996, 'Introduction', in J. Witte \& J.D. van der Vyver, Religious human rights in global perspective. Religious perspectives, pp. XVII-XXXV, Martinus Nijhoff Publishers, The Hague.

Witte, J., 2000, Religion and the American constitutional experiment, Westview, Boulder, CO. 